\title{
A Participatory Action Research Method in a Rural Community of Mexico*
}

Una investigación acción participativa en una comunidad rural de México

Enviado: 1ํo de marzo de 2015 | Revisado: 1ํ de junio de 2015 | Aceptado: 1o de agosto de 2015

\author{
Rubi Arellano** \\ FABRICIO E. BALCAZAR *** \\ University of Illinois, Chicago, Estados Unidos \\ FRANCISCO AlVARADO **** \\ Illinois Division of Rehabilitation Services, Chicago, \\ Estados Unidos \\ SERGIO SUAREZ ****** \\ Federación de Jaliscienses del Medio Oeste, Illinois, \\ Estados Unidos
}

doi:10.11144/Javeriana.upsy14-4.parm

Para citar este artículo: Arellano, R., Balcazar, F. E., \& Suárez, S. A Participatory Action Research Method in a Rural Community of Mexico. Universitas Psychologica, 14(4), 1197-1208. http://dx.doi. org/10.11144/Javeriana.upsy14-4.parm

* Artículo de investigación. Este projecto se completo con la ayuda de la Federacion de Jaliciences en el Medio Oeste (FEDEJAL) y la Division de Servicios de Rehabilitacion de Illinois

** Rubi Arellano < rarellano@vrmil.org>

*****Fabricio@uic.edu

****** Francisco.Alvarado@Illinois.gov

******* sergiodsuarez@gmail.com

\section{A B S T R A C T}

For several decades, community interventions have promoted community development with strategies involving capacity building, advocacy, social change, and empowerment. Although community interventions intend to ameliorate social and economic inequalities, there is still a need to evaluate the outcomes of Participatory Action Research (PAR). PAR approaches have demonstrated to be a helpful tool for addressing and identifying community issues and strengths, while leading community members into action. The PAR approach described in this case study of Ciudad Renace (Town Reborn) — the Concerns Report Method (CRM) — provided a process for the community to come together and identify main issues, organize, and take actions. The findings suggest multiple activities and outcomes in areas like environmental contamination, social services, and education. Participatory methodologies like the Concerns report Method provided opportunities for community members to become engaged in pursing issues and addressing their own needs. The implications for community psychology research and practice are discussed.

Keywords

participatory action research; concerns report method; community development; community psychology; empowerment

\section{RESUMEN}

Por varias décadas, las intervenciones comunitarias han promovido el desarrollo comunitario con estrategias que implican creación de capacidades, promoción, cambio social y empoderamiento. Aunque las intervenciones comunitarias tienen la intención de mejorar las desigualdades sociales y económicas, todavía hay una necesidad de evaluar los resultados de la Investigación Acción Participativa (IAP). Los enfoques IAP han demostrado ser una herramienta útil para el direccionamiento y la identificación de problemas y fortalezas de la comunidad, al mismo tiempo que alientan a los miembros de la comunidad a la acción. El enfoque IAP descrito en este estudio de caso sobre la Ciudad Renace con el Concerns Report Method (CRM) provee de un proceso que permite a la comunidad llegar a identificar en conjunto, sus principales problemas, organizarse y tomar acciones. Los hallazgos sugieren múltiples actividades y resultados en áreas como la contaminación ambiental, los servicios sociales y la educación. Las metodo- 
logías participativas como el CRM brindan oportunidades a los miembros de la comunidad para que se involucren en la búsqueda de sus propios problemas y hacer frente a sus necesidades. Se discuten las implicancias para la investigación y la práctica de la psicología comunitaria.

Palabras clave

investigación acción participativa; CRM; desarrollo comunitario; psicología comunitaria; empoderamiento

Trickett, Espino and Hawe (2011) assert that community interventions have been used increasingly in fields like public health, health promotion, community psychology and prevention science. Many community interventions have focused on developing, implementing, and evaluating health promotion and prevention programs (Brunk \& Goeppinger, 1990; Mulroy \& Lauber, 2004; Strachan, Wright \& Hancock, 2007). The forms in which community interventions have been implemented have varied widely across these fields. However, promoting overall community development is more challenging than trying to address a particulate problem. More recently, community interventions have increased the use of strategies that emphasize community development involving capacity building, advocacy, social change and empowerment (Ohmer \& Korr, 2006; Strachan et al., 2007).

One methodology for promoting community development is Participatory Action Research (PAR). The use of PAR has increased over the last 20 years in the social and health science research. This increase is due to the potential of PAR approaches to improve the relationship between research and practice, address social justice issues and empower people to take ownership in the process of transforming their own social reality (Cargo \& Mercer, 2008). PAR approaches have been successful in addressing and identifying many community issues and strengths.

Selener (1997) defined Participatory Action Research as "a process through which members of an oppressed group or community identify a problem, collect and analyze information, and act upon the problem in order to find solutions and promote social and political transformation" (p. 17). The PAR approach integrates the research process with active collaboration and participation of the underprivileged in order to promote transformative actions. PAR has the potential to generate scientific knowledge with the involvement of the people most affected by the issue being studied.

The community psychology literature suggests that PAR approaches can be used to build a group's capacity for self-advocacy in a manner that helps foster the improvement of life conditions (Balcazar, Garcia-Iriarte \& Suarez-Balcazar, 2009). Hence, empowering methodologies such as PAR are useful to organize community efforts to identify needs and solve problems in underserved populations. Ultimately, the PAR process can provide research participants with a sense of control over their lives that lead them into an empowerment process to promote social change (Trickett et al., 2011). On the other hand, there are some obstacles that can affect the implementation of empowering methodologies. Montero (2009) performed a literature review of community research and identified factors that challenge community intervention such as that the researcher might differ from community members with regards to priorities, interests, needs, personal history, activities scheduled, and conceptual issues. Disagreement might cause potential conflicts in the relationship.

The PAR approach described in this case study of Ciudad Renace (Town Reborn) provided a process for the community to come together and identify main issues, organize and take actions.

\section{The Concerns Report Method as a Participatory Action Research Approach}

The methodology used for this case study was the Concerns Report Method (CRM). This is a participatory action-oriented strategy designed to identify issues, brainstorm solutions, and take actions from the perspective of community members (Fawcett, Seekins, Whang, Muiu \& Suarez de Balcazar, 1984). There is ample evidence to support the role of the CRM as a PAR strategy (Fawcett, Suarez de Balcazar, Whang-Ramos, Seekins, Bradford, \& Mathews, 1988), since the CRM uses a survey which involves community members in the deci- 
sion-making process early on, thereby increasing their likelihood of getting actively involved and staying involved. The method is a reliable, systematic, and simple way to tap into information about the community (Community Tool Box, 2014). The Concern Report process increases knowledge and critical consciousness by promoting critical awareness of common concerns and opportunities for change (Fawcett, White, Balcazar, Suarez-Balcazar, Mathews, Paine-Andrews, Seekins \& Smith, 1994).

In this PAR process, community members play an active role in the creation of the concerns survey. The purpose of the concerns survey is to identify primary community needs. The survey is distributed to as many local people as possible. The survey results are then analyzed, shared, and discussed with the community members in public forums. In these meetings, community members create a plan of action that addresses the identified concerns and strengths. This type of action is consistent with Selener's (1997) assertion that "one of the major goals of PAR is to solve problems at the community level" (p. 12).

The validity and reliability of the CRM have been established. Research suggests that there are overall high ratings of helpfulness, completeness and representativeness of the CRM and that it is useful in measuring the needs of citizens with disabilities (Fawcett et al., 1988). Schriner and Fawcett (1988) found high rates of validity and reliability for a concern survey developed by low-income families (as cited in Balcazar et al., 2009). Fawcett et al. (1988) performed a test-retest reliability to assess whether the CRM produced similar results on repeated measurements. The CRM was highly consistent across time points, with approximately $90 \%$ of the importance ratings and $80 \%$ of the satisfaction ratings varying by one rating point or less. Taken together, this research suggests that the CRM is a valid and reliable methodology for assessing community concerns. A Spearman rank correlation between responses of 405 subjects to the same survey items on a survey developed by people with disabilities at 18-month intervals suggests that scores were highly consistent $(r s=0.94, z=10.85$, $p<0.001$ ) (Balcazar et al., 2009).

\section{Project background}

The target town is a small rural community near the city of Guadalajara, in the east-central part of the state of Jalisco, México. The community has a population of 13,218 persons, 6,675 men and 6,543 women and around $57.69 \%$ of the residents are younger than 29 years old (COEPO, 2010). Overall, $97.51 \%$ of city inhabitants are catholic and $4.27 \%$ of the households depend financially on their relatives living in the United States for the past five years (COEPO, 2010).

The Santiago River is one of the longest rivers in Mexico, and it runs adjacent to the length of the town. The river has been increasingly polluted for the past forty years. One of the industrial corridors of Guadalajara is located near the river, so the industrial waste is dumped directly into the Santiago River without any type of treatment to filter-out contaminants. The Santiago River is one of the most serious health threats for the residents of the town. This has led to an increase in respiratory diseases, heart disease, cancer, and chronic stress, among others conditions (IMDEC, 2007). A few active leaders of the community have documented their complains about the river for the past two decades with the hope of securing support from the appropriate governmental entities. Believing that the local, state and federal governments were not taking their health-related issues seriously, the community began to organize itself for action in 2009. The lack of response from the authorities contributed to the creation of a cohesive movement among residents of the municipality. This movement facilitated the initiative that is the subject of this study.

\section{Case study: Ciudad Renace}

Ciudad Renace (Town Reborn) was an initiative that involved collaboration from multiple agencies seeking to work with community members to address the needs of the town, in the state of Jalisco (Mexico). The Federation of small business owners and regional clubs from the Mexican State of Jalisco in the United States (FEDEJAL), the Club 
Pro-Obras para la Ciudad (a Chicago-based club of immigrants from the town), the Government of the State of Jalisco, the University of Illinois at Chicago (UIC), the Necahual Foundation (a Chicago-based charity created to promote youth development efforts in the city of Guadalajara), and the Municipality of the town teamed up to create a transnational program focused on identifying community strengths and challenges and addressing the needs identified by the community members. One of the authors from the University of Illinois at Chicago (UIC) introduced the CRM as the participatory methodology to identify the community needs and use its findings to promote social change. The Ciudad Renace initiative was started by immigrants living in the Chicago area. As shown in Figure 1, the CRP process has 6 phases; the following is a brief description of the phases as they were implemented in the town.

\section{Development of the collaborative partnership}

Leaders from FEDEJAL in Chicago contacted the UIC researcher to ask for advice about how to proceed with trying to help the community in a meaningful way. They originally considered the possibility of conducting a census of the community in order to better understand its composition. The UIC researcher proposed to use the CRM in order to identify needs, determine priorities and set an agenda for action. The proposal was well received and a meeting was arranged with the executive committee of FEDAJAL to make a formal presentation of the proposal. This was also a way to start a dialogue about the steps in the process. A month later, the UIC researcher was invited to visit the town and held meetings with key community leaders to discuss the idea. This step was also important in order to gather the necessary support from local community leaders and their ideas about how best to proceed. At this point, all of the organizations mentioned earlier agreed to participate and support the initiative and two town residents volunteered to coordinate the process.

Reflection on values and central functions of the community

This phase requires the development of a matrix that allows the formulation of specific items for

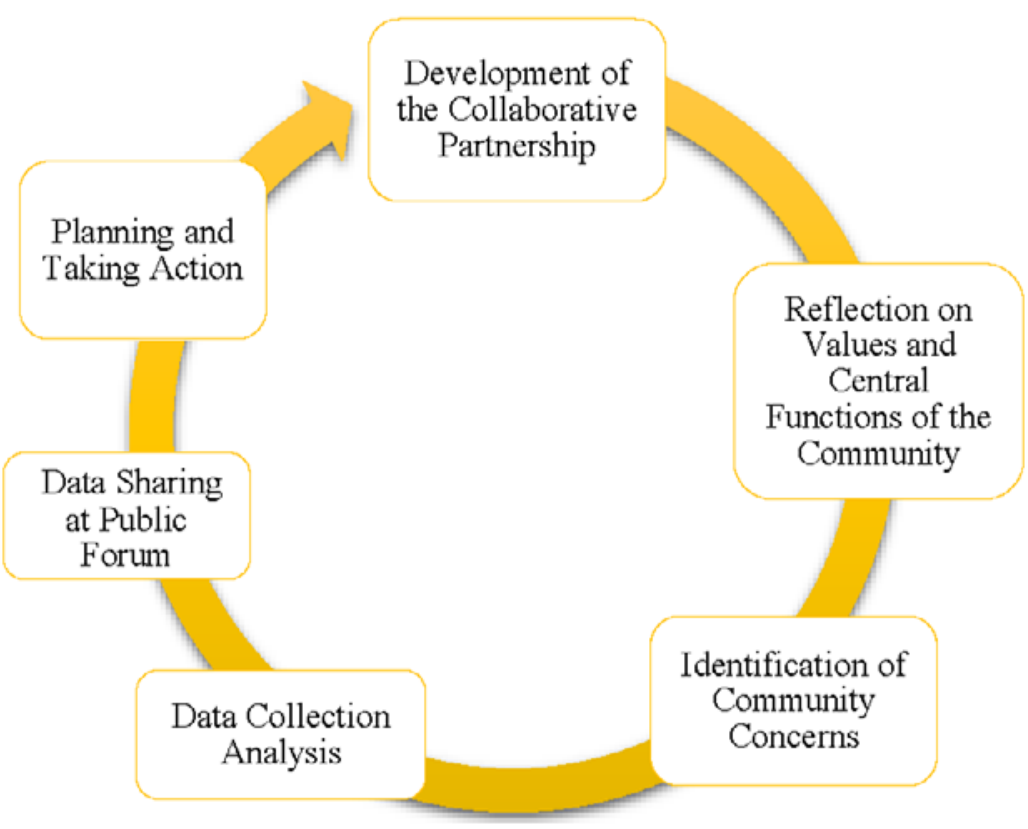

Figure 1: Main phases of the CRM implemented in the town

Source: own work 
the development of the concerns survey (Balcazar, Garcia-Iriarte \& Suarez Balcazar, 2009). It is important that community members collaborate and contribute in deciding what issues are most important to them (Community Tool Box, 2012). A group of community leaders from the town met with the UIC researcher to identify relevant community functions and values. This small group of leaders reflected different interests, values, ages, experiences and community geographic locations. They helped to generate the guiding framework for the development of the concerns survey-a table with community values and critical functions. The group included a political candidate from the party that has been promoting the cleaning and sanitizing of the river, the Parish priest, a long-time farmer from the township, and the mayor at that time. This group held an initial meeting to discuss the research process and identify potential participants for the next phases. The meeting also allowed community leaders to ask questions about the process in order to facilitate understanding of the tasks and resources that were going to be required to collect the surveys.

\section{Identification of community concerns and strengths}

A critical step in the process was to identify the most important community needs and strengths in the town. Therefore, a representative group of community leaders and town residents collaborated to develop the CRM survey. Guidance was provided by the UIC researcher and a Chicago state employee from the Department of Rehabilitation Services (DRS). These volunteers were native Spanish speakers and Hispanic, so language and cultural differences were minimal. Further, special care was taken to become aware of potential cultural differences. Based on the table of values and community functions created during the previous phase, a team of 12 community leaders and community representatives participated in the development of a preliminary list of survey items. The final draft survey was pilot tested with the help of five community volunteers. This pilot test helped modify and clarify questions to insure proper wording. The final survey had a total of 53 items. A demographic section included 15 questions and it was at the beginning of the survey. These questions included age, gender, marital status, education level, and types of disabilities in the household. The survey was created in Spanish. The concerns survey section included two types of questions for each issue. The first question asked about the importance of a particular issue ("How importance is it for you that..."). The second question asked about the respondent's satisfaction with the issue ("How satisfied are you with..."). Both questions were rated on a 5-point scale, where 1 indicated not important or not satisfied and 5 indicated very important or very satisfied.

\section{Data collection and analysis}

Once the survey was finalized, the state government of Jalisco printed the survey. The town's former mayor asked support from a neighboring town High School and the National College of Technical Occupational Education (CONALEP) to collect the data. A group of 30 volunteer students canvassed the community door-to-door to collect the concerns surveys. The students were trained by the two local project coordinators who in turn had been trained by the UIC researcher. The students collected the data as part of their community service requirement to graduate from the school. The mayor supported the initiative, and facilitated the transportation during the data collection phase. The data collection was held over a period of 1 month and a half during the weekends. Only residents living in the municipality of the town were asked to respond the survey. A total of 1,228 people responded; the average age of the respondents was 44 years. Participants were $60 \%$ female and $40 \%$ male. A total of $53 \%$ of the participants had family members at the United States and they reside mainly at California (64\%) and Chicago (18\%).

Table 1 summarizes the list of the top community strengths and concerns identified by the residents. Strengths were items that had high ratings in both importance and satisfaction, while concerns were rated high in importance but low in 
satisfaction (CTB, 2012). These results were the topics targeted for action by community members.

\section{Data sharing at public forum}

The results of the survey were summarized in a brief report and shared during Sunday masses and at a community public forum held in the town's downtown plaza on a Sunday after mass. This report was also posted in the Mayoral office. Furthermore, there was a representative from the state government of Jalisco who attended the town hall meeting. During the town hall meeting, the mayor directed the discussion of the strengths and concerns identified by the community. Attendees were asked to provide additional information to explain the problems and how they perceived them. It was obvious that the majority had very strong feelings about the pollution in the river and that became a priority concern. Promoting the culture of Jalisco through dance and music was of interest to many teachers and parents of children and youth. Community members were asked to join various committees that fit their personal interests (e.g., environmentalist joined the river pollution committee; teachers and parents of school children joined a cultural committee; etc.).

\section{Planning and taking action}

Community leaders used the survey results for planning and taking actions. Some of the proposals included: The need to increase the promotion of social activities that enhance community traditions such as celebrating family day to strengthen families; provide opportunities such as field trips for children to visit museums in Guadalajara; organize soccer tournaments for children and youth; conduct a traditional religious play on Christmas; etc. They also proposed to increase community services and to work with the elementary school teachers to identify vulnerable children. Some of the ideas for new services included, preventing violence against children; offering early intervention workshops to improve early child development among low-income families; and handcrafting classes for youth. In reference to activities that build community capacity, participants proposed to distribute environmental information on the status of the river's condition in order to increase awareness among the population about the river's pollution and the health risks that it poses, and the group nominated a leader who would focus on improving the economic conditions in the agricultural fields near town. Some members also proposed to esta-

TABLE 1

Strengths and concerns of the community

\begin{tabular}{lcc}
\hline Issues & $\begin{array}{c}\text { Percentage level } \\
\text { of importance }\end{array}$ & $\begin{array}{c}\text { Percentage level } \\
\text { of satisfaction }\end{array}$ \\
\hline Strengths of the community & & \\
\hline Feel proud of being a town's citizen & $82.7 \%$ & $85.6 \%$ \\
Preserve the traditions and culture of the town & $85.9 \%$ & $80.9 \%$ \\
Be an active member of the community & $89.9 \%$ & $76.3 \%$ \\
Conserve and protect the town's grassland areas & $84 \%$ & $80.8 \%$ \\
Crime detection and prevention & $89.4 \%$ & $75.6 \%$ \\
\hline Concerns of the community & & \\
Creation of good quality employment in the community & $84.2 \%$ & $56.3 \%$ \\
Demand to the government to penalize companies and/or individuals that & $89.8 \%$ & $66 \%$ \\
pollute the river & $87.8 \%$ & $64.6 \%$ \\
Develop a project to produce local crafts & $83 \%$ & $58.6 \%$ \\
Increase the opportunities to attend the university & $88.2 \%$ & $66.6 \%$ \\
Ideas for production and manufacture & $83.3 \%$ & $60.5 \%$ \\
Opportunities to have a cheap and decent housing & $83 \%$ & $61 \%$ \\
\hline
\end{tabular}

Note: Percentages indicate the level of importance and satisfaction in a scale from 1 to 100 .

Source: own work 
blish a committee in order to build a multipurpose center where they could hold community meetings and also offer visitation services for families with a death relative who did not have space in their home.

\section{Results}

The initiative's general coordinator and promoter was the former president of FEDEJAL who is from the town and lives in Chicago. At that time, he had good relationships with the local and state government, and with local community leaders to start the initiative. Through the Club Pro-obras para la Ciudad, he was able to gather funding from immigrants living in the Chicago area and the Mexican government, and brought together human resources in order to start the initiative.

After the CRM results were analyzed and published, community members came together to suggest some ideas to address the main concerns and increase the strengths that were identified. Therefore, the need to create a non-for profit association came out. The main objective of this association was to increase community social services and promote activities that enhance community traditions. Community leaders decided to create a nonfor profit association called Necahual México A.C. Necahual mission was to help children and family members who live in vulnerable environments and to provide educational, cultural, and recreational activities. Necahual operates with funds donated by immigrants living in the Chicago area. Necahual created a social service delivery unit to offer support services and prevention to families affected by domestic violence (UAVI acronym in Spanish for Unidad de Atención a la Violencia Intrafamiliar). The unit provides free preventive, legal services, and psychological therapies. In 2011, UAVI provided 27 psychological services to community members; in 2012 there were 45 services; in 2013 there were 70 services; and in 2014 through the month of June there were 70 . Hence, the initiative general coordinator sought the support from the University of Guadalajara to have clinical psychologists conduct their internship program at Necahual. Currently, the University of Guadalajara is collaborating with
3 clinical psychologists to cover the growing demand for services. Among the social activities performed by Necahual were: annual field trips for children to Trompo Mágico a children's museum and the park zoo in to Guadalajara; soccer tournaments; religious plays in December; Christmas celebrations; mini Olympic games, family's day celebration, children's day celebration, and handcraft classes. The handcraft classes failed due to lack of community participation.

The general coordinator informed Club ProObras de la Ciudad members about a Mexican government program called $3 \times 1$, and how the clubs could benefit from it. The $3 \times 1$ is a program created by the Mexican federal government to support immigrants' efforts to improve the living conditions in their hometowns. This program involves the participation of the federal, state, and local governments, and hometown associations in the U.S. to facilitate community development and productive projects. In the $3 \times 1$ program, for each dollar donated by an immigrant group, each layer of government donates a dollar, so a 1 dollar donation can potentially become $\$ 4$. The $3 \times 1$ program's objectives are to benefit communities with high levels of poverty, to promote social developmentcommunity projects, to reinforce civil society and government partnerships and strengthen Mexican immigrants' relationships with their hometowns (SEDESOL, 2014).

The activities performed with the purpose of raising funds by the Club Pro-Obras de la Ciudad include: an annual gala dance, a raffle, and a traditional Mexican dance. The Club also organizes a yearly family picnic (free of cost) to promote fraternization among members and an annual event called "Jalisco in Evanston" with traditional music, dance, and food to promote the richness of Mexican culture in Chicago, also free of charge.

Before the Club Pro-Obras de la Ciudad joined the Ciudad Renace initiative, the Club only helped the town nursing home for elderly people. After the unification, the Club started to benefit from the federal government 3x1 program and expanded its mission to meet different community needs. The Club donated to the nursing home a 16 passengers 
mini-bus accessible for people with disabilities, five hospital beds, home appliances and furniture, built an elevator inside the nursing home, installed new doors in the rooms, made the bathrooms safe and accessible, repaired the kitchen drain and the gas line, and upgraded the nursing home electric system. Furthermore, the Club supported the nursing home with funds to start a project for growing organic vegetables. The project consists of harvesting organic vegetables in partnership with the CONALEP students. The students are helping residents grow the vegetables as part of a school course. The profits generated by the vegetables sales are going to help the nursing home.

The Club Pro-Obras de la Ciudad supported the town's church by providing resources to remodel the local funeral home and the multiple-use community center. In 2012, Club Pro-Obras de la Ciudad staff traveled to the town in order to choose students who needed university scholarships the most (based on financial need). The Club donated seven scholarships to students that for lack of economic resources were at risk to abandoning their university studies. In 2013, the Club only awarded three scholarships due to the local government lack of support (the newly elected mayor was no longer supporting the $3 \times 1$ program). Further, the Club contributed to the town fire department with firefighter professional equipment, and donated an ambulance to the town's hospital that provides lowcost health services.

Another community need that resulted from the survey needs assessment was to decrease the river pollution and its health risks. Hence, the former mayor sought support from state and federal governments, and the national water commission, with the purpose of getting resources to decrease the Santiago river's pollution. At the time, a child drowned in the Santiago River due to the high levels of pollutants. This event was widely publicized in the local and Guadalajara newspapers. Therefore, the mayor and community members took advantage of this sorrowful event to lobby the state government to build a treatment plant to clean the water. An article from La Jornada -a well-known national Mexican newspaper- informed that after the mayor and community members lobbied the state government to build a treatment plant to clean the water, on March 2011 the Governor of the state of Jalisco inaugurated the first industrial waste water filtration treatment plant with an investment of over a quarter of a million dollars (Periódico del

TABLE 2

Community concerns addressed by the Ciudad Renace initiative

\begin{tabular}{|c|c|c|}
\hline Strength & Actions & Outcomes \\
\hline $\begin{array}{l}\text { Preserve the traditions and culture of } \\
\text { the town }\end{array}$ & $\begin{array}{l}\text { Founding Necahual Mexico } \\
\text { Christmas Celebrations } \\
\text { Catholic religious play } \\
\text { Annual Field trips for Children } \\
\text { Family's Day celebration } \\
\text { Children's Day Celebration } \\
\text { Organize sports events } \\
\text { Start services from UAVI }\end{array}$ & $\begin{array}{l}\text { Increase the wellbeing of the } \\
\text { community and promotion of social } \\
\text { activities }\end{array}$ \\
\hline Be an active member of the community & $\begin{array}{l}\text { Remodel Multi-use community } \\
\text { center }\end{array}$ & $\begin{array}{l}\text { The center is now being used for } \\
\text { funerals, classes, and meetings of } \\
\text { community organizations as needed }\end{array}$ \\
\hline Concern & Actions & Outcomes \\
\hline $\begin{array}{l}\text { Increase the opportunities to attend the } \\
\text { university }\end{array}$ & University students scholarships & $\begin{array}{l}\text { Financial aid to students that for lack } \\
\text { of economic resources were in risk to } \\
\text { abandoning their university studies }\end{array}$ \\
\hline $\begin{array}{l}\text { Demand the government to penalize } \\
\text { companies and/or individuals that } \\
\text { pollute the river }\end{array}$ & Water filtration Treatment plant & $\begin{array}{l}\text { Decrease the Santiago river's pollution } \\
\text { and its health risks }\end{array}$ \\
\hline
\end{tabular}

Source: own work 
Sur, 2011). However, the State of Jalisco's Water Commission Lab conducted follow up analyzes of the water quality on January 2012 at the level adjacent to the town to determine the quality of the river water and found that although there was an improvement, the river water continues to be seriously polluted and the levels of contaminants exceed the acceptable limits for human utilization nor will these levels promote the preservation or capacity to sustain aquatic life (CEA, 2012). On July 2014, the new president of Mexico Enrique Peña Nieto, inaugurated construction of the nation's largest water treatment plant near the Santiago river, called Agua Prieta. This plant can process 8,500 liters of sewage per second. The water quality after the treatment process generated by Agua Prieta will have sufficient quality for use in agriculture (La Jornada, 2014). Table 2 summarizes some of the community concerns identified with the CRM in the town that were addressed by the activities generated by the Ciudad Renace initiative.

\section{Discussion}

The CRM is a systematic participatory process for setting agendas for community change from the perspective of those who share a common predicament (Balcazar et al., 2009). Including the citizens as partners in the research process is fundamental to ensuring that the research is responsive to their needs and values. In addition, that collaborative effort can improve the quality and applicability of the research (Balcazar, Garate-Serafini \& Keys, 2004). A fundamental goal of the Concern Report process is to provide accurate information about community problems and solutions from the perspective of the people directly affected by the issues (Fawcett, et al., 1994). This study illustrated an implementation of the CRM with positive results. In effect, the community members and immigrants living in the Chicago area took ownership of their hometown issues and worked together to improve their social conditions. The findings suggest that the CRM is an effective tool that community psychologists can use to help community members identify their issues, resources and motivate them to engage in activities to pursue social change.

Overall, the activities implemented by this initiative promoted social development, reduced health risks, and increased community services. These results coincided with Trickett, Espino and Hawe (2011) argument that community interventions are useful to increase public health and health promotion. Moreover, this case study of Ciudad Renace is consistent with Ohmer and Korr (2006), and Strachan et al. (2007) conclusion that community interventions can generate capacity building, advocacy, social change, and empowerment.

The data showed that the Ciudad Renace initiative promoted community involvement, government participation, and the collaboration from local, state and international institutions. This initiative was an important first step to create awareness, learning, outreach, and to begin the community empowerment process. The PAR process performed at the town introduced an ideology of collaboration and citizen responsibility. The data collected in this study illustrates how Ciudad Renace was a transnational initiative that facilitated the union of immigrants living in the Chicago area and the town's community members. The Ciudad Renace initiative was an example of shared responsibility over community needs and teamwork among different layers of the Mexican government, immigrants, local and international educational institutions, the Catholic Church, local community members, and non-profit associations. The residents of the town and immigrants from the town living in the Chicago area organized efforts and took actions in order to address the most pressing needs that were affecting community well-being.

The empowerment process is linked to increasing the knowledge of community members. In this case, that knowledge includes an understanding of the relevant social context of the community, the goals that were attained, resources utilized, and the ways in which future goals could be met (Bennet \& Chapman, 2010). Ciudad Renace has a high probability of continuing to meet the needs of the local population and strengthen their future. Moreover, the information presented in this study shows that 
the PAR approach conducted in the Ciudad Renace initiative has the potential to generate knowledge about the involvement of the people living in marginalized conditions. Many groups are likely to benefit from using a PAR approach to develop meaningful services and goods that improve their life conditions. The PAR approach has the potential to increase the capacity of a community group to take an active role in decisions that affect their quality of life and advocate for services needed according to their own perspectives.

In this case, Necahual continues to fund the operation of UAVI and to perform cultural and recreational events in the community. In addition, the Ciudad Renace initiative has functioned as a facilitator for immigrants living in Chicago to come together to enhance the town's community development. The Club Pro-Obras de la Ciudad continues its mission and projects even though the current state government stopped supporting the Club's projects (the $3 \times 1$ program is no longer being implemented because of concerns that the new governments at the state and local levels are asking for exclusive administration of the funds and the lack of transparency makes the process ripe for corruption).

The PAR process facilitated the creation of $\mathrm{Ne}$ cahual Mexico A.C. and the strengthening of the Club Pro-Obras de la Ciudad. It is important to note that both institutions continue organizing community efforts to solve problems and create opportunities for social change in the town. Recently, the annual gala event generated $\$ 6,000$ in profits to fund the projects for 2015. Finally, the genuine willingness to help their hometown from the general coordinator, the immigrants and community volunteers created a transparent process to build trust and credibility with respect to the Ciudad Renace initiative. Participants involved in the initiative did not receive any economic compensation. The accomplishments were documented and published through social media, newspapers, videos, and pictures.

\section{Limitations}

There are at least two limitations that should be mentioned. The first concerns the capacity to ge- neralize the findings to other populations given the unique characteristics of the individuals and institutions involved in Ciudad Renace. The town is a small rural Mexican community with strong family values and local pride. The community had a very strong participation among the immigrants in the Chicago area and a strong leadership. The leadership also had personal connections with the Governor of Jalisco, the University of Illinois at Chicago, a State agency, and close relationships with the priest and the town mayor at the time of the start of the PAR process. All these relationships had an impact on the effectiveness of the process which makes it unique. Further research is needed to examine how PAR methodologies work when applied within communities that lack these types of resources and supports.

Second, this study summarizes the overall process of PAR and focuses on the leader's unique perspective on how the Ciudad Renace initiative was implemented and its outcomes. However, it would be advisable to assess the experience from community members who were not directly involved in the initiative. Future research may try to focus on understanding the perceptions, experiences or opinions that the Ciudad Renace initiative had on the common residents of the town.

\section{References}

Balcazar, F. E., Garcia-Iriarte, E., \& Suarez-Balcazar, Y. (2009). Participatory action research with Colombian immigrants. Hispanic Journal of Behavioral Sciences, 31(1), 112-127.

Balcazar, F., Garate-Serafini, T. J., \& Keys, C. B. (2004). The need for action when conducting intervention research: The multiple roles of community psychologists. American Journal of Community Psychology, 33, 243-252.

Bennet-Cattaneo, L., \& Chapman, A. R. (2010). The process of empowerment: A model for use in research and practice. American Psychologist, 165(7), 646-659.

Brunk, S. E., \& Goeppinger, J. (1990). Process evaluation: Assessing re-invention of community-based interventions. Evaluation 82 The Health Professions, 13(2), 186-203. 
Cargo, M., \& Mercer, S. L. (2008). The value and challenges of participatory research: Strengthening its practice. Annual Review of Public Health, 29, $325-350$

CEA. Comisión Estatal del Agua de Jalisco. (2012). Resultados del monitoreo de calidad del agua del Río Santiago. Monitoreo 2012. Retrieved from: http:// www.ceajalisco.gob.mx/notas/resultados_monitoreo.html

COEPO (2010). Information sociodemográfica por colonias, Jalisco 2010, [Sociodemographic information by suburbs]. Retrieved from: http://coepojalisco. blogspot.com/2012/11/informacion-sociodemografica-por.html

Community Tool Box. (2014). Concern survey. Retrieved from: http://ctb.ku.edu/en/tablecontents/sub_section_main_1045.aspx

Fawcett, S. B., Seekins, T., Whang, P. L., Muiu, C., \& Suarez de Balcazar, Y. (1984). Creating and using social technologies for community empowerment. Prevention in Human Services, 3, 145-171.

Fawcett, S. B., Suarez de Balcazar, Y., Whang-Ramos, P. L., Seekins, T., Bradford, B., \& Mathews, R. M. (1988). The concerns report: Involving consumers in planning for rehabilitation and independent living services. American Rehabilitation, 14(3), 17-19.

Fawcett, S. B., White, G. W., Balcazar, F. E., SuarezBalcazar, Y., Mathews, R. M., Paine-Andrews, A., \& Smith, J. F. (1994). A contextual-behavioral model of empowerment: Case studies involving people with physical disabilities. American Journal of Community Psychology, 22(40), 471-496.

IMDEC, Instituto Mexicano para el Desarrollo Comunitario A.C. \& VIDA Instituto de Valores Integrales y Desarrollo Ambiental A. C.. (2007). Martires del Rio Santiago: Informe sobre Violaciones al Derecho a la Salud y a un Medio Ambiente Sano en Juanacatlan y el Salto, Jalisco, México. Juanacatlán, Jalisco, Mexico: IMDEC.

La Jornada. (2008, February 14). Muere niño intoxicado en Jalisco; el gobernador defiende presa. La Jornada. Retrieved from: http://www.jornada.unam. $\mathrm{mx} / 2008 / 02 / 14 /$ index.php?section= estados\&arti $\mathrm{cle}=028 \mathrm{n} 2 \mathrm{est}$
La Jornada. (2014, July 22). Inauguran planta de Tratamiento de aguas residuales de Agua Prieta. La Jornada. Retrieved from: http://www.lajornadajalisco.com.mx/2014/07/23/inauguran-la-plantade-tratamiento-de-aguas-residuales-de-agua-prieta-tercera-mas-grande-de-al/

Montero, M. (2009). Scopes and obstacles in community empowerment. Universitas Psychologica, 8(3), 615-626.

Mulroy, E. A., \& Lauber, H. (2004). A user-friendly approach to program evaluation and effective community interventions for families at risk of homelessness. Social Work, 49(4), 574-586.

Ohmer, M., \& Korr, W. S. (2006). The effectiveness of community practice interventions: A review of the literature. Research on Social Work Practice, 16(2), 132-145.

Periódico del Sur. (2011, March 15). Inauguran planta de tratamiento de aguas residuales en Juanacatlán. Periódico del Sur. Recuperado de: http://www. periodicoelsur.com/noticia.aspx?idnoticia $=56794$ SEDESOL (2014).

Selener, D. (1997). Participatory action research and social change. Ithaca, NY: Conell University, The Cornell Participatory Action Research Network.

Schriner, \& Fawcet. (1988) Development and validation of a Community Concerns Report Method. Journal of Community Psychology, 16(3), 306-313.

Strachan, G., Wright, G. D., \& Hancock, E. (2007). An evaluation of a community health intervention programme aimed at improving health and wellbeing. Health Education Journal, 66(3), 277-285.

Trickett, E. J., Espino, S. R., \& Hawe, P. (2011). How are community interventions conceptualized and conducted? An analysis of published accounts. Journal of Community Psychology, 39(5), 576-591.

Unidad de Atención a las Violencias de Género y Familiar (UAVI). (2011). Modelo de la unidad de atención a las violencias. Aguascalientes: IMAA Recuperado de: http://www.agscumple.gob.mx/ phpSIME/evidencias/bak_2013-01-31_modelo\%20 Uavi\%20.pdf 
